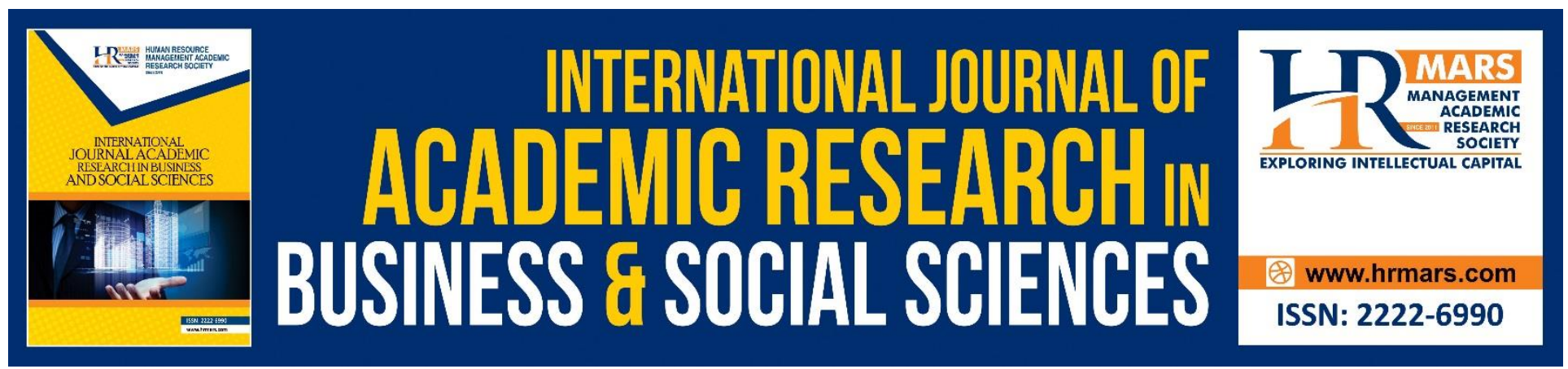

\title{
An Empirical Analysis of Saving Behavior among Malaysian Employees
}

Shafinar Ismail, Nadia Syazwani Khairuddin, Nurul Ezaili Alias, Wei Loon-Koe, Rozana Othman

To Link this Article: http://dx.doi.org/10.6007/IJARBSS/v8-i10/4822

DOI: $10.6007 /$ IJARBSS/v8-i10/4822

Received: 11 Sept 2018, Revised: 13 Oct 2018, Accepted: 23 Oct 2018

Published Online: 28 October 2018

In-Text Citation: (Ismail, Khairuddin, Alias, Loon-Koe, \& Othman, 2018)

To Cite this Article: Ismail, S., Khairuddin, N. S., Alias, N. E., Loon-Koe, W., \& Othman, R. (2018). An Empirical Analysis of Saving Behavior among Malaysian Employees. International Journal of Academic Research in Business and Social Sciences, 8(10), 1070-1080.

Copyright: (c) 2018 The Author(s)

Published by Human Resource Management Academic Research Society (www.hrmars.com)

This article is published under the Creative Commons Attribution (CC BY 4.0) license. Anyone may reproduce, distribute, translate and create derivative works of this article (for both commercial and non-commercial purposes), subject to full attribution to the original publication and authors. The full terms of this license may be seen

at: http://creativecommons.org/licences/by/4.0/legalcode

\section{Vol. 8, No. 10, 2018, Pg. 1070 - 1080}

Full Terms \& Conditions of access and use can be found at http://hrmars.com/index.php/pages/detail/publication-ethics 


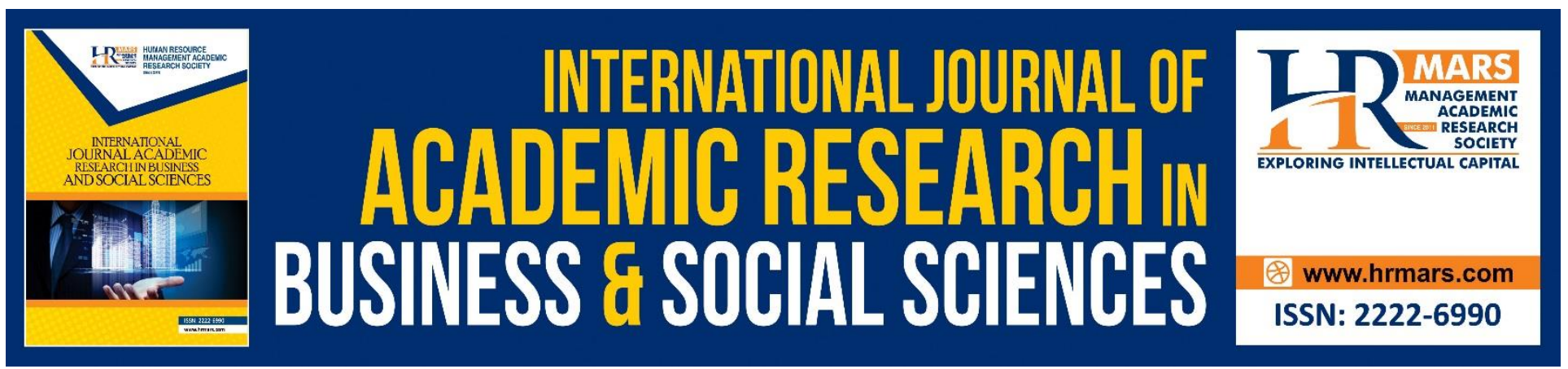

\title{
An Empirical Analysis of Saving Behavior among Malaysian Employees
}

\section{Shafinar Ismail, Nadia Syazwani Khairuddin, Nurul Ezaili Alias, Wei Loon-Koe, Rozana Othman}

Faculty of Business and Management; Universiti Teknologi MARA, Melaka, Malaysia

\begin{abstract}
People were found to be more conscious on spending their money. Therefore, it is important to identify the savings behavior as people are more to spend rather than to save. Overspending can lead to various implications, such as bankruptcy because of the inability to settle up their unpaid payments to creditors (Zhu, 2011). However, there is a lack of research on the determinants of factors affecting the saving behavior. Thus, the aim of the study is to identify the factors affecting the saving behavior. Three determinants are identified which are as follows: services quality, religious belief and knowledge. Questionnaires were distributed to the 150 respondents. The sampling procedure adopted was purposive sampling. The data obtained were analyzed using SPSS which involves scale reliability, descriptive, and regression analysis. Semi-structured interviews were conducted to crosscheck the quantitative findings. The result indicates that services quality, religious belief and knowledge influence saving behavior. This study makes a contribution to the literature on saving behavior. The findings achieved in this study will be of interest for practitioners and academics concerned with money management skills in order to become financially independent for long term. Keywords: saving behavior, questionnaire, regression analysis, semi-structured interviews
\end{abstract}

\section{Introduction}

People need the personal-finance management in their lives as decisions made in early adulthood will impact a person's entire life, especially decisions that adversely affect credit and finances. The importance to this study is to identify the factors affecting saving behavior. It is important to identify the saving's behavior as people are more to spend rather than to save as saving money is very useful for emergencies (Barnes et al., 2011), future used (Griskevicius et al., 2013) and also for retirement. Overspending can lead to various implications, such as bankruptcy because of the inability to settle up their unpaid payments to creditors (Zhu, 2011). Personal bankruptcy issues have been a pressing concern to the governments, bankers, creditors, and financial researchers in recent years. Offering important body of information to financial institutions helps them evaluate the risk of their credit portfolio in a timely manner, as well as helping them to formulate their respective risk management strategies (Min \& Lee, 2008). People who failed in managing their personal financial can lead to the 
financial problem such as bankruptcy when they do not have money to pay their debt and this will bring on a feeling of embarrassment, stress, guilt, and anger. Apart from that, when someone does not plan their personal financial very well, they will face difficulties in developing their lives such as delaying marriage or not getting married at all, postponing having children (Ismail et al., 2011). Notably, in 2015, it was reported in the Annual Report of Malaysia Department of Insolvency that the average of bankrupt individuals per day was 51 and there were 83 cases of personal bankruptcy being registered per day (Malaysia Department of Insolvency, 2016). In the same year, the Secretary General of the Federation of Malaysian Consumers Associations (FOMCA), Datuk Paul Selvaraj indicated that the rising cost of living, moderate salary increments and low retirement savings would only worsen the situation if the personal bankruptcy issue was not addressed soon (Carvalho \& Hamdan, 2015).

Savings are likely to play a very important role in promoting real growth. Several empirical studies found a positive effect of the saving rate on the long term growth (Cardenas and Escobar (1998), Motely (1994) and Krieckhaus (2002). People's savings, in particular, assist in smoothing out unexpected variations in income, minimizing the impact of shocks on consumption. In a country like the Malaysia, where a lot of resident in rural area are engaged in agriculture and face uncertainty from weather and natural calamities, it would be helpful to understand how people deal with fluctuations in incomes. Further, savings serve as a vehicle of social mobility and of enhancing future income earning possibilities. Savings indeed have implications in the welfare of households, macroeconomic, growth and development. In the Malaysia, however, it has been noted that the savings rate is becomes fluctuate overtime. On the other hand, there is a possibility that Malaysian are actually saving more but not through formal financial instruments. Previous studies on savings look at differences in the saving behaviour of urban and rural households. Some studies focus on the forms and determinants of rural savings. Due to the inadequacy of recent and comprehensive data and information regarding the behaviour of household savers through time, the study designed to increase savings interest. From some fact that researcher found, it proof that saving is one of the important things that should be concern by consumer and government. In addition, saving can be used during peak situation such as during inflation time.

Therefore, the researcher intends to analyze what are the factors that affecting the saving behavior in Malaysia. The following section considers previous studies relevant to saving behavior, while next section presents the details for the methodology to achieve the study objectives. Most importantly, section 4 analyses the findings generated from the survey work. In the section 5 , a further discussion of results and study implications are highlighted in order to gain more understanding on factors affecting saving behavior, followed by a conclusion.

\section{Theoretical Background and Literature Reviews}

Saving is the money that person has saved, especially through bank or official scheme. There are many reasons for saving. Keynes (1936), stated that there are three motives for saving, which were for transaction, precautionary, and speculative. Modigliani and Brumberg (1954), suggest that individuals formulate financial plans for retirement (Browning and Lusardi, 1996). Individual practice saving habit throughout their lifetime, beginning slowly in their early years, peaking during forties and fifties and finally accumulating sufficient funds to retire (Karpel, 1995); however, according to 
Modigliani and Brumberg (1954), saving levels are low for the young, rise and peak during the middle years, then become lower again among the old.

Service's quality is the customer's overview of the service's component of a product and estimating it helps to understand how the customers satisfy with the product and services or not (Goeldner and Ritchie, 2006). Usually, a service quality links between what customer's wish from a service and what they perceive that they received (Mackay and Crompton, 1988). Good quality of services will give to the customer satisfaction, employee satisfaction and profitability (Nakhai and Neves, 2009). According to Varoglu and Eser,(2006) customer no longer just expect good and best quality goods but also high levels of service provided along with them. For this study, service's quality can be related with the service's quality provided by a bank. Example of it is in terms of how friendliness the banker at the counter; good brand's product offers by bank and time taken to entertain the customers. Therefore, we make the following hypothesis:

\section{$H_{1}$ : Services Quality has significant relationships with the saving behaviour}

Apart from service's quality, religion also plays an important role in effecting the saving behaviour Mitchell, 2003). According to Beyerlein \& Hipp (2006), religion has a significant impact on individuals, group and community measures of civic life. Religiosity is the extent to which an individual has integrated the tenet of a particular religion into his or her attitudes, values and beliefs (King and Williamson, 2005). Religion usually encourages their followers to save money and do not waste money. Therefore, the following hypothesis is constructed:

$\mathrm{H}_{2}$ : Religious belief has significant relationships with the saving behaviour

There are a variety of sources through which knowledge can be acquired. The knowledge of the importance of saving can be gained from education. These include formal education, such as high school or college course, seminars and training classes outside of school as well as informal sources such as from parents, friends, and work (Keller and Staelin 1987). The amount of savings has been associated positively with knowledge, which comes from education, wealth, income and age (Browning and Lusardi, 1996). People who are financially knowledgeable are more likely to behave in financially responsible ways (Hilgert, Hogarth, and Beverly, 2003). Bodie, (2002) stated that individuals repeatedly made the same mistakes in not saving their money because of insufficient knowledge of the importance of saving money. Therefore, we hypothesize:

$\mathrm{H}_{3}$ : Knowledge has significant relationships with the saving behaviour Following from the discussion in the previous section, the following theoretical model is developed as presented in Figure 1.

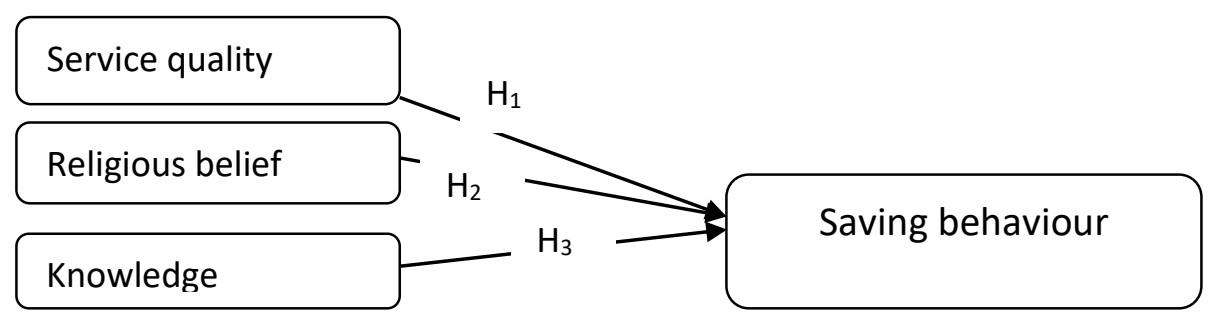

Figure 1. Research Model 
INTERNATIONAL JOURNAL OF ACADEMIC RESEARCH IN BUSINESS AND SOCIAL SCIENCES

Vol. 8, No. 10, Oct. 2018, E-ISSN: 2222-6990 @ 2018 HRMARS

\section{Methodology}

This study employs mixed methods for the purpose of data collection. The benefit of using mixed methods is to clarifying that the data are communicating what we think they are; this notably strengthens the integrity of conclusions drawn from the data. For instance, in this study, quantitative approach (a questionnaire survey) have been implemented, followed by semi-structured interviews, in order to test, on a larger scale, the findings generated as a result of the literature review with the use of the structured questionnaires presented to a large sample of respondents. Semi-structured interviews were conducted to cross-check the quantitative findings.

The population for this research consists of the private sectors employees. In this study, the sampling design is purposive sampling. The data on this study are generated from responses to questionnaires completed at the actual survey. A total of 150 questionnaires are provided. We employ SPSS 20.0 in order to conduct frequency analysis, descriptive analysis, reliability and regressions' analysis. Frequency analysis is used to extract the percentile of the profiles of respondents in terms of their gender, ethnics, age, religion, marital status and monthly income obtained. Mean and standard deviation are computed for descriptive analysis. The reliability test is used to examine the internal consistency among the items in their respective factors. Regression analysis is particularly used to test the hypotheses proposed earlier.

\section{Empirical Result}

RESPONDENTS' PROFILE

Most of the respondents in this study are female, which represent 57.3 percent while male respondents are 42.7 percent. Out of 150 respondents, 58.7 percent are married followed by single with 40.7 percent and divorced 0.7 percent. The age ranges between 20 - 30 with $54.0 \%$ followed by between 31 - 40 with 29.3 percent; and $>40$ are 14.0 percent and <20 with 2.7 percent. Most of the respondents were Malay who represents 62 percent followed by Chinese with 20.7 percent followed by Indian with 13.3 percent, and the least races were others with 4.0 percent. 61.3 percent are Muslim followed by Buddhist with 15.3 percent, Hindu 12.7 percent, Christian 7.3 percent and others with 3.3 percent. For education level, 57.3 percent have Bachelor Degree followed by Diploma with 18.7 percent; Masters Degree with 13.3 percent and Sijil Pelajaran Malaysia (SPM) are 10.7 percent. Most of the respondents have the monthly scale salary at range $>\mathrm{RM} 4,000$ with 33.3 percent followed by RM1,000-3,000 with 30.7 percent, RM3, 001 to 4,000 with 30 percent. This study found that most of the respondents saved their money at Maybank with 51.3 percent, followed by CIMB bank with 18.0 percent, RHB bank 14.7 percent, Bank Islam 11.3 percent and others 4.7 percent.

\section{DESCRIPTIVE ANALYSIS}

Table 1 illustrates the descriptive analysis results. Firstly, variables of 'saving behaviour' is explained by item 'Always Save Money' gets the highest mean with 3.88 and 'Saving in Equal Amount' is the lowest mean by 3.01. Thus, it indicates that item 'Always Save Money' has the strongest influence towards saving behaviour. The mean of 3.88 on a five point scale for media advertisement indicates that most of the respondents are neither bent neutral nor agree. The standard deviation of 1.18 shows how much variation or dispersion exists from its mean. The minimum number of one on variable of 'saving behaviour' indicates that there are respondents who strongly disagree with the 
INTERNATIONAL JOURNAL OF ACADEMIC RESEARCH IN BUSINESS AND SOCIAL SCIENCES Vol. 8, No. 10, Oct. 2018, E-ISSN: 2222-6990 @ 2018 HRMARS

items saving behaviour and maximum number of five indicates some respondents are strongly agree with the items on the saving behaviour. Secondly, the variable of 'services quality' is explained by item 'Friendly services at counter' gets the highest mean with 4.36 and 'services quality has an impact on saving' is the lowest mean by 3.37. Thus, it indicates that item 'Friendly services at counter' has the strongest influence on services quality towards saving behaviour. The standard deviation of 0.95 shows how much variation or dispersion exists from its mean. Thirdly, the variable of 'religion' is explained by item 'teach not to waste' gets the highest mean with 4.27 and 'strong sprit' is the lowest mean by 3.71. Thus, it indicates that item 'teach not to waste' has the strongest influence on religion towards saving behaviour. The standard deviation of 1.01 shows how much variation or dispersion exists from its mean. Fourthly, the variable of 'knowledge' is explained by item 'know the importance of saving' gets the highest mean with 4.19 and 'enough knowledge' is the lowest mean by 3.77. Thus, it indicates that item 'know the importance of saving' has the strongest influence on knowledge towards saving behaviour. The standard deviation of 1.01 shows how much variation or dispersion exists from its mean.

Table 1. Descriptive Analysis

\begin{tabular}{|c|c|c|c|}
\hline Variables & Items & Mean & Standard Deviation \\
\hline \multirow{6}{*}{ Saving Behavior } & Always save Money & 3.88 & 0.87 \\
\hline & Saving Every Month & 3.76 & 0.89 \\
\hline & Saving in Equal Amount & 3.01 & 1.08 \\
\hline & Record Saving and Spending & 3.09 & 1.18 \\
\hline & Aware with the spend & 3.59 & 0.98 \\
\hline & Avoid spending on unnecessary things & 3.65 & 1.02 \\
\hline \multirow{6}{*}{ Services Quality } & Impact & 3.37 & 0.95 \\
\hline & Influence & 3.50 & 0.82 \\
\hline & Time taken & 4.15 & 0.68 \\
\hline & Friendly services at counter & 4.36 & 0.66 \\
\hline & Lot of self-banking services (ATM) & 4.10 & 0.79 \\
\hline & Good brands product & 3.81 & 0.81 \\
\hline \multirow{6}{*}{ Religious belief } & Encouraging & 3.98 & 0.86 \\
\hline & Teach not to waste & 4.27 & 0.75 \\
\hline & Strong sprit & 3.71 & 0.99 \\
\hline & As a Guidance & 3.77 & 0.98 \\
\hline & Healthy lifestyle & 3.91 & 0.98 \\
\hline & Positive Attitude & 3.76 & 1.01 \\
\hline \multirow{6}{*}{ Knowledge } & Enough Knowledge & 3.77 & 0.69 \\
\hline & Interested to Know & 3.87 & 0.81 \\
\hline & Know the Importance of saving & 4.19 & 0.68 \\
\hline & Can fulfill desire & 4.09 & 0.74 \\
\hline & Experience financial difficulties & 4.14 & 0.67 \\
\hline & Should have Knowledge & 4.13 & 0.68 \\
\hline
\end{tabular}


INTERNATIONAL JOURNAL OF ACADEMIC RESEARCH IN BUSINESS AND SOCIAL SCIENCES Vol. 8, No. 10, Oct. 2018, E-ISSN: 2222-6990 ㄷ 2018 HRMARS

Source: Developed for current study

\section{RELIABILITY ANALYSIS}

Table 2 demonstrates the result of reliability test, whereby the Cronbach's alpha reliability coefficient is obtained for the all variables. Most of the variables are above 0.70 , and it is considered acceptable to measure for this study. Out of six variables, five is above 0.7 except for the services' quality with 0.67. Firstly, measuring saving behaviour; the result is 0.79. According to Sekaran and Bougie (2010), it is considered as acceptable. Secondly, in measuring service's quality; the result is 0.67 , which is considered acceptable. Next, in determining religious belief, the result is 0.89 , which is considered as very good. Further, in measuring the knowledge, the result is 0.83 , which is considered as very good. In a nutshell, coefficient was obtained from all questions in Likert Scale are reliable.

Table 2. Reliability Analysis

Source: Developed for current study

\begin{tabular}{|l|l|l|}
\hline Variables & Cronbach's Alpha & N of Items \\
\hline Saving Behavior & 0.79 & 6 \\
\hline Services Quality & 0.67 & 6 \\
\hline Religious belief & 0.89 & 6 \\
\hline Knowledge & 0.83 & 6 \\
\hline
\end{tabular}

\section{REGRESSION ANALYSIS}

Multiple regression analysis is a statistical technique to predict the variance in the dependent variable by regress it with the independent variables, besides assessing the degree and character of the relationship between the independent variables with the dependent variable (Sekaran \& Bougie, 2010). Table 4 demonstrates the regression results. Services Quality is significantly associated with saving behaviour $\left(t=2.95, p=0.00\right.$. Hence, $H_{1}$ is supported. It is also shown that religious belief is significantly related to saving behaviour $(t=4.60, p=0.00)$. Hence, $\mathrm{H}_{2}$ is supported. It also suggests that knowledge are significantly associated with saving behaviour $(t=3.37, p=0.00)$. Hence, $\mathrm{H}_{3}$ is supported.

Table 4. Regression Results

\begin{tabular}{|l|l|l|l|l|l|}
\hline & Hypotheses & Beta & t-value & p-value & Accepted? \\
\hline $\mathrm{H}_{1}$ & $\begin{array}{l}\text { Services Quality has significant } \\
\text { relationships with the saving } \\
\text { behaviour }\end{array}$ & 0.02 & 2.95 & 0.00 & Yes \\
\hline $\mathrm{H}_{2}$ & $\begin{array}{l}\text { Religious belief has significant } \\
\text { relationships with the saving } \\
\text { behaviour }\end{array}$ & 4.35 & 0.00 & Yes \\
\hline
\end{tabular}


INTERNATIONAL JOURNAL OF ACADEMIC RESEARCH IN BUSINESS AND SOCIAL SCIENCES Vol. 8, No. 10, Oct. 2018, E-ISSN: 2222-6990 @ 2018 HRMARS

\begin{tabular}{|l|lc|l|l|l|l|}
\hline $\mathrm{H}_{3}$ & $\begin{array}{l}\text { Knowledge has significant } \\
\text { relationships with the saving } \\
\text { behaviour }\end{array}$ & 0.26 & 3.37 & 0.00 & Yes \\
\hline
\end{tabular}

Source: Developed for current study

$\mathrm{H}_{3}$ is fully supported as the relationship between knowledge and saving behaviour is significant. People who are financially knowledgeable are more likely to behave in financially responsible ways (Hilgert, Hogarth, and Beverly, 2003). The amount of savings has been associated positively with knowledge. An example of the comment from respondents includes:

'.... know that many banks offers variety of services related to savings... some offers very good package.... If I open saving account now in ten years' time I will the benefits from savings...'

Furthermore, quality of the service and religious belief also plays important role towards saving behaviour. The result from quantitative survey shows that both have statistically significant relationship with saving behaviour; thus, results indicate that both $\mathrm{H}_{1}$ and $\mathrm{H}_{2}$ are fully supported. Respondents in the follow-up interviews also confirmed this result, with respondents stating the following, for example:

'...i am concern of services offers by the banks...customer service is very important for me ....

'... believe saving money for future education is very important... my parents teach me not to waste...'

\section{Conclusion, Implication and Future Research}

The purpose of this study is to investigate the issue with respect to the factors that affecting the saving behaviour. Results of this study suggest that religious belief, knowledge and service's quality affects saving behaviour.

This study advances current knowledge by shedding light on some important factors related to saving behaviour. This study explains the effects of service's quality, religious belief, and knowledge towards saving behaviour. It is worth noting that this study proposes a conceptual model as a framework to understand the determinants of saving behaviour.

The present study has three limitations. Firstly, the sample of this study is relatively small. Only 150 respondents involved in this study. Although this sample size meets the minimum requirement for multivariate analysis (Hair et al. 2010), larger samples are able to inflate the statistical power. Secondly, we choose only employees at private sector, which may explain that our findings may not generalize to employees in other sectors. Future studies thus are encouraged to include different samples to increase the generalizability of findings. Despite the mentioned limitations, this study offers with an improved understanding of factors influencing saving behaviour.

\section{Corresponding Author}

Shafinar Ismail

Universiti Teknologi MARA, Cawangan Melaka, 78000 Alor Gajah, Melaka, Malaysia, Email: shafinar@bdrmelaka.uitm.edu.my/shafinar138@gmail.com 
INTERNATIONAL JOURNAL OF ACADEMIC RESEARCH IN BUSINESS AND SOCIAL SCIENCES

Vol. 8, No. 10, Oct. 2018, E-ISSN: 2222-6990 C 2018 HRMARS

\section{References}

Avery, R. B., \& Arthur, B. K. (1991). Household Saving in the U.S. Review of Income and Wealth, 37(4), 409-432.

Barnes, Z., Miller, C., Verma, N., and Collins, M. J., \& Walsh, K. (2011). Save, spend, or pay down debt: Financial literacy and decisions among low-income households (Working paper). Center for Financial Security.

Bernheim, B. D. (1991). The vanishing nest egg: Reflection on saving in America, New York: Priority Press Publications.

Bodie, Z. (2002). An Analysis of Investment Advice to Retirement Plan Participants. The Wharton School, University of Pennsylvania. PRC WP 2002-15.

Browning, M., \& Lusardi, A. (1996). Household Saving: Micro Theories and Micro Facts. Journal of Economic Literature, 34, 1797-1855.

Burtless, B. G., \& Sabelhaus, J. (1991). The Decline in Saving: Evidence from Household Surveys. Brookings Papers on Economy Activity, 1, $183-241$.

Davison, W. P. (1983). The third-person effect in communication. Public Opinion Quarterly, 47, 1-15.

Duflo, E., \& Saez, E. (2003). The role of information and social interactions in retirement plan decisions: Evidence from a randomized experiment. Quarterly Journal of Economics 68: 815 842.

Goeldner, C.R., \& Ritchie, J.R.B. (2006). Tourism: Principles, practices, philosophies: Wiley.

Griskevicius, V., Ackerman, J. M., Cantú, S.M., Delton, A. W., Robertson, T. E., Simpson, J. A., Thompson M. E., \& Tybur, J. M. (2013). When the Economy Falters, Do People Spend or Save? Responses to Resource Scarcity Depend on Childhood Environments. Psychological Science, 0, $0956797612461919 v 1-956797612461919$

Hair, J.F, Black, W.C., Babin, B.J. \& Anderson, R.E. (2010.) Multivariate Data Analysis. Upper Saddle River: Prentice-Hall.

Hilgert, M. A., Hogarth, J.M, \& Beverly, S. G. (2003). Household Financial Management: The connection between Knowledge and Behaviour. Federal Reserve Bulletin, 89(7), 309 - 322. 
INTERNATIONAL JOURNAL OF ACADEMIC RESEARCH IN BUSINESS AND SOCIAL SCIENCES

Vol. 8, No. 10, Oct. 2018, E-ISSN: 2222-6990 ㄷ 2018 HRMARS

Ismail, S., Serguieva, A., \& Singh, S. (2011). Integrative Model to Students' Attitude to Educational Loan Repayment: A Structural Modelling Approach, Journal of International Education in Business, 4 (2), 125-135.

Kapoor, J. R., Dalabay L. R., \& Hughes, R. J. (2012). Personal Finance, Tenth Edition. New York: McGraw- Hill.

Karpel, C. S. (1995). The Retirement Myth. New York: Harper Collins.

Katona, G. (1975). Psychological economics. New York: Elseveir Scientific Publishing Company.

Keller, K. L., \& Staelin, R. (1987). Effects of Quality and Quantity of Information on Decision Effectiveness. Journal of Consumer Research, 1-31.

Kessler, R. C. (1997). The effects of stressful life events on depression. Annual Review of Psychology, 48.

King, J.E. and Williamson, I. (2005). Workplace Religious Expression, Religiosity and Job Satisfaction: Clarifying a Relationship. Journal of Management, Spirituality and Religion, 2(2), 173-198.

Keynes, J.M. (1936). The general theory of employment interest and money. London: Macmillan.

Mackay, K.J., \& Crompton, J.L. (1998). A conceptual model of consumer evaluation of recreation service quality. Leisure Studies, 7(1), 40-49.

Mitchell, J. \& Marriage, S. (2003). Mediating religion: Conversations in media, religion and culture. London: T\&T Clark.

Modigliani, F., \& Brumbergh, R. (1954). Utility Analysis and the Consumption Function: An Interpretation of Cross-Section Data. Brunswick, N. J.: Rutgers University Press.

Nakhai, B., \& Neves, J. S. (2009). The Challenges of Six Sigma in Improving Service Quality. International Journal of Quality and Reliability Management.

Olander, F., \& Seipel C. (1970). Psychological Approaches to the study of Saving. Urbana, Illinois: University of Illinois.

Ostrowski, P.L., O’Brien, T.V., \& Gordon, G.L. (1993). Service quality and customer loyalty in the commercial airline industry. Journal of Marketing, 22 (2), 16-24.

Parasuraman, A., Zeithamal, V.A., \& Berry, L.L. (1998). SERVQUAL: Multiple item scale for measuring consumer perceptions of service quality. Journal of Retailing, 64 (1), 12-40. 
INTERNATIONAL JOURNAL OF ACADEMIC RESEARCH IN BUSINESS AND SOCIAL SCIENCES

Vol. 8, No. 10, Oct. 2018, E-ISSN: 2222-6990 @ 2018 HRMARS

Sekaran, U. (2003). Research Methods for Business, A Skill Building Approach (4 ${ }^{\text {th }}$ edition). New York: John Wiley \& Sons.

Sekaran, U., \& Bougie, R. (2010). Research Methods for Business. A Skill-building Approach (5th ed.). Haddington: John Wiley \& Ltd.

Southwell, B. (2005). Between messages and people. Communication Research, 32(1), 112-140.

Varoglu, D., \& Eser, Z. (2006). How Service Employees can be Treated as Internal Customers in Hospitality Industry (Electronic Version). Cambridge: The Business Review, 5 (2), 30. 